\title{
Alzheimer's Disease associated with Psychiatric Comorbidities
}

\section{MICHELLE L. GARCEZ, ANA CAROLINA B. FALCHETTI, FRANCIELLE MINA and JOSIANE BUDNI}

Programa de Pós-Graduação em Ciências da Saúde, Laboratório de Neurociências, Unidade Acadêmica de Ciências da Saúde, Universidade do Extremo Sul Catarinense, Av. Universitária, 1105, 88806-000 Criciúma, SC, Brasil

Manuscript received on January 9, 2015; accepted for publication on June 19, 2015

\begin{abstract}
Alzheimer's disease (AD) is the most common cause of dementia and has become a severe public health issue. It is estimated that globally, $35.6 \%$ of people have some form of dementia. This number is expected to double by 2030 , and possibly even triple by 2050 . The disease is associated with deficits in cognition/ memory and a reduced ability in coping with everyday life. Moreover, patients can experience behavioral alterations such as mood swings, depression and hallucinations. Therefore, it is common to find the presence of neuropsychiatric comorbidities such as depression, schizophrenia and bipolar disorder during the course or development of AD. These disorders can become severe enough to interfere with the patients daily functioning, and can worsen the course of the disease. However, little is known about the causal relationship between psychiatric comorbidities and $\mathrm{AD}$, or the reasons for the predisposition of some individuals to such disorders. Therefore, the purpose of this review is to clarify the causal relationship between depression, schizophrenia and bipolar disorder with AD.
\end{abstract}

Key words: Alzheimer's disease, bipolar disorder, depression, schizophrenia.

\section{INTRODUCTION}

Alzheimer's Disease (AD) is recognized as the major cause of dementia in modern society, and may result in significant limitations for sufferers through cognitive impairment. The most evident symptom in early $\mathrm{AD}$ is progressive memory loss (Grundman et al. 2013).

Studies seek to elucidate the pathophysiology of $\mathrm{AD}$ which is related to cognitive damage. Possible biochemical causes include the accumulation of amyloid beta protein oligomers, which are responsible for synaptic damage and sequent memory deficit in AD (Krstic and Knuesel 2013). Furthermore, hyperphosphorylation of the

Correspondence to: Josiane Budni

E-mail: josiane.budni@unesc.net
Tau protein is another pathophysiological process involved in AD. Hyperphosphorylation induces the formation of intracellular neurofibrillary tangles, leading to neuronal death and the progressive loss of neuronal function (Krstic and Knuesel 2013), (Serrano-Pozo et al. 2011), (Chu 2012), (Nimmrich and Ebert 2009).

Despite their being studies that indicate possible biochemical causes that lead to acute neurodegeneration over time (Shankar and Walsh 2009), the pathophysiology of AD is not still elucidated. However, it is suggested that some etiological aspects may be involved in the development of $\mathrm{AD}$, such as environmental and genetic factors (Schipper 2011). 
Considering the present limitations of our understanding of $\mathrm{AD}$, the same issues could appear in the form of cognitive symptoms, which are related to memory, learning, agnosia and apraxia. Also could appear in the form of non-cognitive symptoms, characterized by behavioral and psychological alterations, such as aggressiveness, irritability, hallucinations and depression, which are known as the Behavioral and Psychological Symptoms of Dementia (BPSD) (Schiffczyk et al. 2013).

Neuropsychiatric symptoms are visible both during the development of, and throughout the course of AD (Lyketsos et al. 2011). While the cognitive symptoms of dementia are neuropsychiatric features present in the vast majority of the population regardless of age, the presence of depression associated with dementia appears primarily in the elderly (Steffens et al. 2009). Thus, it is probable that depression is the most common neuropsychiatric disorder in $\mathrm{AD}$ (Contador-Castillo et al. 2009).

For this reason, AD causes a huge economic and social impact, generated by the high costs involved in the health care of patients, such as those involved in the utilization of drug therapy and the provision of full-time caregiver (Schaller et al. 2014). It is worth mentioning that in the United States of America (USA), about $\$ 604$ million dollars are invested annually for the assistance of patients with dementia (WHO 2012).

Thus, this disease has become one of the most severe global public health problems, with its current prevalence effecting $35.6 \%$ of people worldwide, with this number expected to double by 2030 , and possibly even tripling by 2050 (WHO 2012). Moreover, there is an increased risk of the incidence of dementia in later life, which is associated with the prevalence of diseases such as $\mathrm{AD}$, mainly occurring in the seventh or eighth decade of life (Reitz et al. 2011). This demands that better organizational and assistive solutions are required from the health professionals and public health systems that are dealing with these patients, which would help reduce the burden being placed on the patients' families, as well as decrease the high costs involved in the treatment of this disease (Franz et al. 2010).

The symptoms associated with $\mathrm{AD}$ are the major causes that lead to an early patient hospitalization (Sansoni et al. 2013). A study performed with 1014 patients, showed that 90\% of the patients studied had BPSD, and $44 \%$ also showed depressive symptoms. In addition to this, the group also presented a high prevalence of other symptoms such as illusions, hallucinations and delusions in those patients with high scores in the scales of psychiatric symptoms (Fernandez et al. 2010). Furthermore, depression and apathy appear more frequently during $\mathrm{AD}$, with hallucinations, delusions and aggressiveness also being common (Lyketsos et al. 2011).

Considering the high impact that non-cognitive symptoms have upon both the caregivers and the patient's own health, there are considerable costs involved for the public health system. Therefore, the objective of this review is to describe the findings of previously published scientific literature, illustrating the possible associations between patients with $\mathrm{AD}$, and the presence of psychiatric comorbidities including, bipolar disorders, depression and schizophrenia.

\section{BIPOLAR DISORDER AND ALZHEIMER'S DISEASE}

Bipolar disorder (BD) is a psychiatric disorder characterized by episodes of mania or hypomania and depression (Brenner and Shyn 2014). The DSM (Diagnostic and Statistical Manual of Mental Disorders) is a document that reflects the consensus among leading academics, physicians and researchers in the field of mental health and psychiatric diseases (Vahia 2013). The latest version of the document was published by the American Psychiatric Association (APA) in May 2013, this being its fifth edition (DSM-5 or DSM-V). This latest edition of the DSM brings some modifications 
to the concepts of bipolar disorder, mainly affecting the inclusion and exclusion criteria.

BD is still classified as bipolar disorder I and II. Bipolar disorder I is characterized by manic episodes (extremely elevated mood), mixed states (dysphoria) and major depression. Bipolar disorder II is characterized by episodes of major depression and at least one hypomanic episode (elevated mood and increased energy). As in DSM-IV, the presence of five of the nine diagnostic symptoms are required with at least one manic episode lasting a week or more (bipolar I) or at least one hypomanic episode lasting four days or more (bipolar II), leading to a total change in the life of the patient (APA 2013).

Before the diagnosis of BD can be confirmed, any medical condition, substance or drug that could induce manic symptoms should be excluded. This is especially significant in geriatric patients, who may have other comorbidities that can cause delirium and/or depression, such as AD. However, more recent studies have demonstrated clinical evidence for a link between $\mathrm{AD}$ and $\mathrm{BD}$, beyond them sharing similar symptoms. Many epidemiological studies have linked these two diseases (Kessing and Andersen 2004), (Zilkens et al. 2014), (da Silva et al. 2013) and have shown findings such as neuroimaging alterations (Rej et al. 2014), dysregulation of neural calcium signaling (Berridge 2013) and epigenetic changes (Rao et al. 2012).

Studies undertaken on BD patients have demonstrated that they have a greater risk of getting a dementia diagnosis than in controls matched by the gender and age of the general population. The risk of dementia increases by $6 \%$ with every episode of bipolar disorder that leads to the hospitalization of the patient. The authors had to indicate that the study only included patients who had been hospitalized at least once, and that affective episodes were included only if they resulted in hospitalization, since the study was conducted using records from hospital admissions in Denmark (Kessing et al. 1999), (Kessing and Andersen 2004). Therefore, the increased risk of dementia in these patients may have been underestimated. However, it should be noted that this evidence is dependent on clinical and demographic variables.

Epidemiological studies have also been conducted on other populations. A matched casecontrol study using Western Australian state-wide hospital records relating to inpatient, outpatient, mental health and emergency admissions which were linked to deaths, demonstrated that in Western Australians aged between 65-84 years, the chances of bipolar disorder patients developing AD was twice as high, while the chances of these patients developing non-specific dementia was six times as high (Zilkens et al. 2014). However, a study by da Silva et al. (2013), which conducted a systematic review on the risk of individuals with affective disorder history developing dementia, demonstrated that the risk of developing dementia was higher when associated with depression than with bipolar disorder, and that depression may be a an important confounding factor, since bipolar patients have alternating depressive episodes.

Bipolar disorder and dementia may share common etiological factors, such as oxidative stress and reduced neurotrophic factors that are both key mediators in the pathophysiology of mood disorders (Bauer et al. 2014) and AD (Heneka et al. 2014), as well as neuroinflammation (Stich et al. 2014), which occurs in both comorbidities, with increases shown in pro-inflammatory interleukin, tumor necrosis factor alpha (TNF- $\alpha$ ) and arachidonic acid cascade enzymes in the postmortem brains taken from BD and AD patients (Kim et al. 2011), (Rao et al. 2011).

Another of the etiological factors common to the comorbidities being discussed are the vascular changes that are observed in patients affected by AD (Luchsinger et al. 2008), (Brickman et al. 2012) which are also seen in BD patients (Sodhi et al. 2012). However, there is still some disagreement over the data pertaining to the cerebrovascular changes found between various studies, because of the different age of the patients and the regions where these changes are found (Almeida et al. 
2009), (Haller et al. 2011), (Rej et al. 2014). Further research is needed to establish the relationship between bipolar disorder and $\mathrm{AD}$, and to ascertain whether these changes are directly related to the cognitive deficits found in both conditions. However, it is known that even after remission of the depressive state, BD patients demonstrate impaired executive function and attention deficits; similarly, euthymic individuals with bipolar disorder have deficits in declarative semantic memory and executive function (Robinson et al. 2006), these alterations also being observed in patients suffering with AD (Bondi et al. 2008)

Another pathway common to both conditions is the inhibition of Glycogen synthase kinase-3 (GSK3). Lithium is a traditional medicine used for treating $\mathrm{BD}$, and it is known that in $\mathrm{BD}$, one of the main intracellular targets of lithium is the inhibition of GSK-3 $\beta$, which regulates the activity of the transcription factors (CREB and $\beta$-catenin) responsible for the expression of BDNF and Bcl-2. These control neurogenesis and neuronal survival, as well as having mood stabilization effects. In addition, lithium increases Bcl-2 expression and decreases the levels of cytosolic calcium by inhibiting the release of $\mathrm{Ca}^{+}$from the endoplasmic reticulum (Berridge 2013). The use of lithium has recently been advocated in the treatment of $\mathrm{AD}$, and the action of the drug may be a bridge between $\mathrm{AD}$ and $\mathrm{BD}$, by operating via the same mechanisms (Stutzmann et al. 2006), since dysregulation of $\mathrm{Ca}^{+}$ signaling occurs in both conditions. It may also simply be acting by decreasing the phosphorylation of the Tau protein, which occurs via the action of GSK-3 $\beta$, as already noted (Hernandez et al. 2013).

Studies have reported reductions in the levels of BDNF and synaptic proteins in the brains of both AD and BD patients (Rao et al. 2011), (Kim et al. 2010), and in addition to this, there have been observations of changes in the expression of inflammatory (Kim et al. 2011) and apoptotic genes (Kim et al. 2010) common to BD and AD. In a study by Rao et al. (2012), post-mortem brains from patients suffering with $\mathrm{BD}$ and $\mathrm{AD}$ showed statistically significant epigenetic changes in global DNA methylation for both $\mathrm{BD}$ and $\mathrm{AD}$, and these epigenetic changes are related to neuroinflammation, synaptic integrity, neuroprotection and arachidonic acid metabolism in the frontal cortex. However, while global histone $\mathrm{H} 3$ acetylation was found to have increased in the brains of BD patients. However, it was not found alter in $\mathrm{AD}$ patients. It should be noted that the medications taken by the patients may have also interfered with the changes found in the epigenome.

Other studies have analyzed the levels of amyloid metabolites contained in the cerebrospinal fluid (CSF) of BD patients, and discovered that there were lower concentrations of the soluble forms of APP ( $\alpha$ and $\beta$ ) in bipolar patients, when compared to healthy controls or AD patients (Piccinni et al. 2012), (Jakobsson et al. 2013) in which the decrease in $\beta \mathrm{A}-42$ in the CSF is inversely proportional to the number of amyloid plaques. An association between low concentrations of $\mathrm{A} \beta$ and an increase in the severity of bipolar disorder type I was also observed, but no other evidence of neurodegeneration for the Alzheimer type was found in bipolar patients (Jakobsson et al. 2013). This finding is in agreement with a previous study in which no increases in amyloid plaques or neurofibrillary tangles were found in the postmortem brain tissues of psychiatric patients (Damadzic et al. 2002).

Thus, the existence of consistent points and similar findings for both $\mathrm{BD}$ and $\mathrm{AD}$ are clear. However, although both disorders seem to have similar underlying mechanisms, there is not enough evidence to say that the cognitive impairment found in BD has the same pathophysiology as that found in $\mathrm{AD}$, nor is it possible to assert that $\mathrm{BD}$ patients are predisposed to AD. The main findings and conclusions are presented in Table I.

\section{DEPRESSION AND ALZHEIMER'S DISEASE}

Depression is a mental disorder characterized by the presence of a number of symptoms including: a depressed mood, a loss of interest in pleasurable 
TABLE I

Associations between AD and bipolar disorder, depression and schizophrenia.

\begin{tabular}{|c|c|c|c|}
\hline $\begin{array}{c}\text { Psychiatric } \\
\text { Comorbidities } \\
\text { associated with AD } \\
\end{array}$ & Article & Authors & Conclusion \\
\hline \multirow{3}{*}{ Bipolar disorder } & $\begin{array}{l}\text { Does the risk of developing dementia } \\
\text { increase with the number of episodes in } \\
\text { patients with depressive disorder and in } \\
\text { patients with bipolar disorder? }\end{array}$ & $\begin{array}{l}\text { Kessing and } \\
\text { Andersen } \\
\text { (2004) }\end{array}$ & $\begin{array}{l}\text { The risk of dementia seems to increase with the } \\
\text { number of episodes in depressive and bipolar affective } \\
\text { disorders. }\end{array}$ \\
\hline & $\begin{array}{l}\text { Plasma beta-amyloid peptides levels: a } \\
\text { pilot study in bipolar depressed patients }\end{array}$ & $\begin{array}{l}\text { Piccinni } \\
(2012)\end{array}$ & $\begin{array}{l}\text { Changes in plasma levels of different } \mathrm{A} \beta \text { peptides } \\
\text { might represent increase of the risk for cognitive } \\
\text { decline in bipolar patients, such as AD. }\end{array}$ \\
\hline & $\begin{array}{l}\text { Epigenetic modifications in frontal } \\
\text { cortex from Alzheimer's disease and } \\
\text { bipolar disorder patients. }\end{array}$ & $\begin{array}{l}\text { Rao et al. } \\
\text { (2012) }\end{array}$ & $\begin{array}{l}\text { Brains from BD and AD patients showed epigenetic } \\
\text { changes in global DNA methylation related to } \\
\text { neuroinflammation, synaptic integrity, neuroprotection } \\
\text { and arachidonic acid metabolism. }\end{array}$ \\
\hline \multirow{9}{*}{ Depression } & $\begin{array}{l}\text { Depression and Risk for Alzheimer } \\
\text { Disease: Systematic Review, Meta- } \\
\text { analysis, and Metaregression Analysis }\end{array}$ & $\begin{array}{l}\text { Ownby et al. } \\
\quad(2006)\end{array}$ & $\begin{array}{l}\text { There is a high relationship between depressive } \\
\text { symptoms and depression as a risk factor for the } \\
\text { development of AD. }\end{array}$ \\
\hline & $\begin{array}{c}\text { Prevalence of depression among older } \\
\text { Americans: the Aging, Demographics } \\
\text { and Memory Study }\end{array}$ & $\begin{array}{l}\text { Steffens et al. } \\
\quad(2009)\end{array}$ & $\begin{array}{l}\text { Individuals with dementia had among the highest } \\
\text { prevalence of current depression. }\end{array}$ \\
\hline & $\begin{array}{c}\text { Contribution of Depression to Cognitive } \\
\text { Impairment and Dementia in Older } \\
\text { Adults }\end{array}$ & $\begin{array}{l}\text { Potter and } \\
\text { Steffens } \\
(2007)\end{array}$ & $\begin{array}{l}\text { The prevalence of depression is highly in most } \\
\text { dementias. In AD may be less intense. }\end{array}$ \\
\hline & $\begin{array}{l}\text { The risk of developing depression when } \\
\text { suffering from neurological diseases }\end{array}$ & $\begin{array}{l}\text { Thielscher et } \\
\text { al. (2013) }\end{array}$ & $\begin{array}{l}51.4 \% \text { of patients developed depression, one year after } \\
\text { the diagnosis of the AD. }\end{array}$ \\
\hline & $\begin{array}{l}\text { Late-life depression and risk of vascular } \\
\text { dementia and Alzheimer's disease: } \\
\text { systematic review and meta-analysis of } \\
\text { community-based cohort studies }\end{array}$ & $\begin{array}{l}\text { Diniz et al. } \\
\quad(2013)\end{array}$ & $\begin{array}{l}\text { Association between late-life depression with the } \\
\text { development of AD. }\end{array}$ \\
\hline & $\begin{array}{l}\text { Increased Hippocampal Plaques and } \\
\text { Tangles in Patients with Alzheimer } \\
\text { Disease with a Lifetime History of } \\
\text { Major Depression }\end{array}$ & $\begin{array}{l}\text { Rapp et al. } \\
\text { (2006) }\end{array}$ & $\begin{array}{l}\text { Was found that of a lifetime history of depression, is } \\
\text { associated the presence of a higher number of neuritic } \\
\text { plaques and neurofibrillary tangles the hippocampus of } \\
\text { the patients with AD. }\end{array}$ \\
\hline & $\begin{array}{l}\text { Plasma amyloid } \beta \text {, depression, and } \\
\text { dementia in community-dwelling elderly }\end{array}$ & $\begin{array}{l}\text { Direk et al. } \\
\quad(2013)\end{array}$ & $\begin{array}{l}\text { The presence of a higher number of neuritic plaques } \\
\text { and neurofibrillary may be present in patients with } \\
\text { depression without AD. Depression may also be } \\
\text { associated with the accumulation of these plaques in } \\
\text { elderly individuals }\end{array}$ \\
\hline & $\begin{array}{l}\text { Serum amyloid beta protein in young } \\
\text { and elderly depression: a pilot study. }\end{array}$ & $\begin{array}{l}\text { Kita et al. } \\
\text { (2009) }\end{array}$ & $\begin{array}{c}\text { Serum Abeta40/42 ratio was higher in depressive } \\
\text { patients. }\end{array}$ \\
\hline & $\begin{array}{l}\text { Neuropsychiatric symptoms in MCI } \\
\text { subtypes: the importance of executive } \\
\text { dysfunction. }\end{array}$ & $\begin{array}{l}\text { Rosenberg et } \\
\text { al. (2011) }\end{array}$ & $\begin{array}{l}\text { Impairment in executive functions, were more severe } \\
\text { in patients with depression and anxiety. People with } \\
\text { features of depressive symptoms also associated with } \\
\text { mild cognitive impairment, was found an increased risk } \\
\text { for the development of AD. }\end{array}$ \\
\hline \multirow{3}{*}{ Schizophrenia } & $\begin{array}{l}\text { Dementia in middle-aged patients with } \\
\text { schizophrenia }\end{array}$ & $\begin{array}{l}\text { Nicolas et al. } \\
\quad(2014)\end{array}$ & $\begin{array}{l}\text { Identified } 14 \text { schizophrenic patients with dementia } \\
\text { among } 96 \text { elderly, but only two were diagnosed with } \\
\text { likely AD. }\end{array}$ \\
\hline & $\begin{array}{l}\text { A common brain network links } \\
\text { development, aging, and vulnerability } \\
\text { to disease }\end{array}$ & $\begin{array}{l}\text { Douaud et al. } \\
\quad(2014)\end{array}$ & $\begin{array}{c}\text { Suggested a common spatial pattern of abnormalities in } \\
\text { a brain network in AD and schizophrenia. }\end{array}$ \\
\hline & $\begin{array}{l}\text { Dysregulation of neural calcium } \\
\text { signaling in Alzheimer disease, bipolar } \\
\text { disorder and schizophrenia }\end{array}$ & $\begin{array}{l}\text { Berridge } \\
(2013)\end{array}$ & $\begin{array}{l}\text { Dysregulation of the } \mathrm{Ca}(2+) \text { signaling pathway is } \\
\text { responsible for development of neural diseases such as } \\
\text { Alzheimer disease, bipolar disorder and schizophrenia. }\end{array}$ \\
\hline $\begin{array}{l}\text { Bipolar disorder, } \\
\text { depression and } \\
\text { Schizophrenia }\end{array}$ & $\begin{array}{l}\text { Severe psychiatric disorders in mid-life } \\
\text { and risk of dementia in late-life (age } \\
65-84 \text { years): a population based case- } \\
\text { control study. }\end{array}$ & $\begin{array}{l}\text { Zilkens et al. } \\
\qquad(2014)\end{array}$ & $\begin{array}{l}\text { Severe depression, bipolar disorder, schizophrenia and } \\
\text { alcoholic dependency disorder in mid-life are important } \\
\text { risk factors for AD in the late-life. }\end{array}$ \\
\hline $\begin{array}{l}\text { Bipolar disorder } \\
\text { and depression }\end{array}$ & $\begin{array}{c}\text { Affective disorders and risk of } \\
\text { developing dementia: systematic review }\end{array}$ & $\begin{array}{l}\text { da Silva et al. } \\
\text { (2013) }\end{array}$ & $\begin{array}{l}\text { Increased risk for dementia in individuals with } \\
\text { depression, and bipolar disorder }\end{array}$ \\
\hline
\end{tabular}


activities, changes in appetite and in sleep patterns, and alterations in psychomotor activities such as difficulty in thinking, concentrating or making decisions (APA 2013). This disorder is commonly associated with an increased risk of morbidity and mortality, an increased utilization of health services, and a reduced response to therapeutic regimens. There is also an increased risk of suicide (Paradela et al. 2005), (Rotheneichner et al. 2014).

There is an increased rate of depression within developed countries when compared to countries of low to middle income (Bromet et al. 2011), (Kessler and Bromet 2013), adulthood is still related to the onset of symptoms, and women have twice the risk of developing depression over a lifetime when compared to men of the same age (Bromet et al. 2011), (Kessler and Bromet 2013). In addition, a population-based study has assessed the prevalence of depression in the Brazilian population, finding a greater rate of depressive symptoms in individuals over the age of 60 (da Silva 2013).

Globally, the prevalence of depressive disorders in the elderly population is between $10 \%$ and $20 \%$, depending on their cultural situations, indicating that it is the most common psychological disorder in the senescence population (Barua et al. 2011). The features attributed to the onset of a major depressive disorder in later life, are also associated with a higher frequency in the development of cognitive impairment (Potter and Steffens 2007), (Steffens et al. 2009).

Studies indicate that there is a strong relationship between depressive symptoms and depression as a risk factor for the development of AD (Ownby et al. 2006), (Thielscher et al. 2013). Two meta-analysis (Diniz et al. 2013) and (Ownby et al. 2006) and one systematic review (da Silva et al. 2013) found an association between late-life depression and the development of AD.

A neuropathological study was performed which assessed the post-mortem brains of 153 participants. It was evident from the findings that depression may be related to neuronal loss in specific brain regions, such as the hippocampus, which also occurs in AD. However, there was no evident association between the effects of depression and $\mathrm{AD}$ in the neurofibrillary tangles or neuritic plaques, which are both characteristic symptoms of AD (Tsopelas et al. 2011). Wilson et al. (2003) also found no correlation between plaques, tangle formation and current depressive symptoms in $\mathrm{AD}$ patients.

A separate prospective study, which conducted a neuropathological evaluation of the post-mortem brains of patients with a mean age of 81 years, found the presence of a higher number of neuritic plaques and neurofibrillary tangle formations in the hippocampus of patients with $\mathrm{AD}$ with a history of depression, as compared with brains of AD patients without depression history (Rapp et al. 2006).

These findings reinforce the hypothesis that neuronal changes are caused by AD. However, these changes may also be present in patients with depression who are not suffering with $\mathrm{AD}$ (Direk et al. 2013), whereas the formation of neurofibrillary tangles and neuritic plaques are one of the main processes involved in the pathophysiology of AD (Nimmrich and Ebert 2009), (Serrano-Pozo et al. 2011), (Krstic and Knuesel 2013). Depression may also be associated with the accumulation of these plaques in elderly individuals (Kita et al. 2009).

Other studies have shown a positive relationship between a depressive state at the time of death, and the presence of neuritic plaques in Alzheimer's disease, which is independent of the clinical severity of dementia. A pre-clinical study has shown that beta-amyloid oligomers leads to memory impairment and depressive-like behavior in mice (Ledo et al. 2013).

Therefore, it can be difficult to differentiate and consequently diagnose the depressive symptoms of dementia, because a symptom from one condition can overlap the other (Bystad et al. 2014). There are mechanisms involved in the depressive process which are characterized by increases in the production of glucocorticoids and in cerebral vascular disease, leading to atrophy of hippocampal ischemia, and ultimately resulting 
in the cognitive decline seen in $\mathrm{AD}$ or dementia (Butters et al. 2008). Therefore, this relationship makes it difficult to determine whether depression is a risk factor for $\mathrm{AD}$ or a prodromal symptom (Koenig et al. 2014).

For example, when assessing 211 elderly women for depression, these patients showed a cognitive deficit in all of the tests performed in the study (Yaffe et al. 1999), yet another current study which evaluated 1,299 women with mean age of 88 years, found that in $41 \%$ of participants there were significant features of cognitive decline, and in those of more than 90 years of age, the association with dementia was more prevalent (Yaffe et al. 2011).

A separate study investigating the prevalence of neuropsychiatric symptoms which assessed 1,799 patients with mild cognitive impairment, found that impairments in executive functions, i.e. cognitive symptoms, were more severe in patients suffering with depression and anxiety (Rosenberg et al. 2011). More recently, they evaluated 527 people who had features of depressive symptoms also associated with mild cognitive impairment. Their findings showed that in this group there was an increased risk for the development of AD (Rosenberg et al. 2013).

These studies suggest that depression might not only be a risk factor for dementia or $\mathrm{AD}$, but may also be a feature symptom of the early stages of cognitive decline or dementia. The main findings and conclusions are presented in Table I.

\section{SCHIZOPHRENIA AND ALZHEIMER'S DISEASE}

Schizophrenia is a severe mental disorder with a prevalence of nearly $1 \%$ of the world's population, and is estimated to have an incidence of 15 per 100,000 people (Rossler et al. 2005). The nature of this disorder is heterogeneous, which makes its treatment and investigation much more difficult (Casey et al. 2013).

The diagnosis of schizophrenia is essentially based on the description of signs and symptoms presented by the patient. To date, there have been no pathophysiological parameters with sufficient sensitivity or specificity to provide a positive diagnosis (Bagdy and Juhasz 2013). According to the DSM-V (Diagnostic and Statistical Manual of Mental Disorders), the signs must have been present for at least six months, and must also include a minimum of one month of active symptoms to confirm the diagnosis (APA 2013). Schizophrenia is a mental disorder characterized by positive, negative and cognitive symptoms. The positive symptoms may be expressed as delirium, hallucinations and delusions (Penzes et al. 2011), (Howes and Murray 2014), (Murray et al. 2014). The negative symptoms involve the blunting of affect. The cognitive symptoms are characterized by problems with working memory (APA 2013).

The mechanisms of this disease are still poorly understood. Dysfunction of the dopaminergic system has been postulated to be a contributing factor. This is in part, on the functional roles of dopamine with respect to physiology, and to the decline of cognitive performance, especially in working memory and in reward circuitry (Arnsten 2011). In addition, there are alterations in the function of one or more neurotransmitter systems, involving the dopaminergic, glutamatergic, serotonergic and adenosinergic systems (Carter 2006). A study comparing the prospective memory of 42 healthy people with 42 people suffering with schizophrenia, showed a deficit in the group of patients with schizophrenia. This reinforces the hypothesis that there is a cognitive impairment in schizophrenia (Kumar et al. 2008).

There are several lines of study that have associated cognitive decline and schizophrenia, and this decline can be related to changes in the frontoparietal neural networks and disorders of the hippocampus (Joyce 2013), which are also associated with AD (Nelson et al. 1998), (Wright et al. 2000). Changes in the white matter within the ventrolateral and dorsolateral regions of the left prefrontal cortex (Quan et al. 2013), and decreased myelination in the temporal and occipital regions 
have been found in patients with schizophrenia and cognitive decline (Palaniyappan et al. 2013). Spatial working memory abilities are impaired in those individuals with a high risk of psychosis (Wood et al. 2003), and this memory alteration is related to AD (Serino et al. 2014).

The cognitive profile of subjects with lateonset schizophrenia differs from those of patients with AD and depression (Ting et al. 2009), (Etkin et al. 2013). Individuals with schizophrenia show cognitive decline at all stages of the disease (Rajji et al. 2014). This cognitive decline can be easily observed by testing for changes in the episodic memory response of people with schizophrenia (Schaefer et al. 2013), (Barch and Sheffield 2014). It can also be observed in the speed at which they process information (Schaefer et al. 2013), (Woodward et al. 2013), as well as in changes to their verbal memory, which is one of the most prevalent cognitive symptoms of schizophrenia (Lepage et al. 2014).

Similarly, psychotic symptoms, delusions and hallucinations are frequent in $\mathrm{AD}$, which is currently the second most prevalent psychotic disorder (second only to schizophrenia) in the USA, and it may become the most prevalent (Murray et al. 2014). The onset of psychotic symptoms in AD is strongly associated with a hastening cognitive decline (Ropacki and Jeste 2005).

There are few conclusive epidemiological studies relating the development of schizophrenia with the onset of AD. This is mainly because diagnosing elderly patients with schizophrenia is challenging, since various stages of cognitive tests are necessary, and also because AD is only diagnosable in patients through psychiatric assessment. Nicolas et al. (2014) identified 14 schizophrenic patients with dementia amongst 96 elderly patients that were under study, and of these, only two were diagnosed with likely AD. Other studies have shown that the cognitive decline typical in schizophrenic patients in later life is not as consistent or as fast as that which is evident neurodegenerative diseases such as AD (Harvey et al. 1995), (Friedman et al. 2001).

However, a recent study has led to discussions on the subject. After adjustment for several known medical risk factors, schizophrenia in mid-life was associated with dementia at ages 65-79 (Zilkens et al. 2014). In addition, Douaud et al. (2014) showed that some brain regions develop relatively late during adolescence, and degenerate rapidly during aging in patients with schizophrenia and AD. These regions are also associated with intellectual ability and episodic memory, with deficiencies in these areas directly contributing to the main symptoms of schizophrenia and AD. Thus, the study suggests that there is a common pattern of brain abnormalities in these two disorders.

Some other common findings are seen in the diseases in question. In a comprehensive genomic analysis studying 108 genes from schizophrenic patients, gene associations were found. These were specifically related to the main assumptions of the etiology and treatment of schizophrenia. Many other genes involved in glutamatergic neurotransmission and synaptic plasticity, in addition to the $C A C N A 1 C, C A C N B 2$ and $C A C N A 11$ genes, which encode subunits of voltagedependent calcium channels, are implicated in the schizophrenia (Schizophrenia Working Group of the Psychiatric Genomics Consortium 2014). $\mathrm{AD}$ is also closely related to calcium signaling, and the upregulation of calcium in neuronal signaling may induce an initial decline in memory. This subsequently progresses into a later phase of apoptosis by excessively activating calcium receptors, and ultimately leads to excitotoxic neuronal death (Berridge 2013). Although the concept of glutamatergic excitotoxicity by calcium signaling is an underlying mechanism in various diseases, this newly discovered link between AD and schizophrenia should be considered.

There are also other findings which are common to both conditions in question, such as a reduction in neurotrophic factors, mainly in the levels of brain-derived neurotrophic factor 
(BDNF) in schizophrenia (Ikeda et al. 2008), and in AD (Alvarez et al. 2014), which is important for neurogenesis. There are also increases in interleukin-1, interleukin-6 and tumor necrosis factor (TNF) in schizophrenia (Potvin et al. 2008), and in AD (Heneka et al. 2014), indicating neuroinflammation and decreased hippocampal volume in both diseases (Mondelli et al. 2011), (Voevodskaya et al. 2014). Therefore, despite being different diseases, AD and schizophrenia are linked; however, there is some disagreement as to how close this link actually is. The main findings and conclusions are presented in Table I.

\section{CONCLUSIONS}

Although no causal relationship has been proven between $\mathrm{AD}$ and the psychiatric disorders in this study, certainly, there is a close relationship between psychiatric comorbidities such as depression, schizophrenia and bipolar disorder and this dementia. Considering that there is still enormous difficulty in identifying AD at earlier stages, understanding of the mechanisms underlying the psychiatric comorbidities and $\mathrm{AD}$, can be useful. The psychiatric comorbidities could be related to an earlier detection of a possible predisposition to development of AD. In turn, the occurrence of depression, schizophrenia and bipolar disorder could be considered a prodromic stage of AD. In particular, this will allow earlier treatment of patients. Moreover, the use of classical drugs for treating these psychiatric comorbidities may possibly have beneficial therapeutic effects in $\mathrm{AD}$.

\section{RESUMO}

A doença de Alzheimer (DA) é a causa mais comum de demência e tornou-se um grave problema de saúde pública. Estima-se que, globalmente, 35,6\% das pessoas têm alguma forma de demência. Este número deverá duplicar até 2030 e, possivelmente, até mesmo triplicar até 2050. A doença está associada com déficits na cognição / memória e uma redução da capacidade em lidar com a vida cotidiana. Além disso, os pacientes podem experimentar alterações comportamentais, tais como alterações de humor, depressão e alucinações. Portanto, é comum encontrar a presença de comorbidades neuropsiquiátricas tais como depressão, esquizofrenia e transtorno bipolar durante o curso do desenvolvimento da DA. Estes distúrbios podem tornar-se graves o suficiente para interferir com o funcionamento diário dos pacientes, e podem piorar o curso da doença. No entanto, pouco se conhece sobre a relação causal entre comorbidades psiquiátricas e a DA, ou as razões para a predisposição de alguns indivíduos a tais transtornos. Portanto, o objetivo desta revisão é esclarecer a relação causal entre depressão, esquizofrenia e transtorno bipolar com a DA.

Palavras-chave: doença de Alzheimer, transtorno bipolar, depressão, esquizofrenia.

\section{REFERENCES}

AlmeidA JR, AKKAL D, HASSEL S, TRAVIS MJ, BANIHASHEMI L, KERR N, KUPFER DJ AND PHILLIPS ML. 2009. Reduced gray matter volume in ventral prefrontal cortex but not amygdala in bipolar disorder: significant effects of gender and trait anxiety. Psychiatry Res 171: 54-68.

ALVAREZ A, ALEIXANDRE M, LINARES C, MASLIAH E AND MOESSLER H. 2014. Apathy and APOE4 are associated with Reduced BDNF Levels in Alzheimer's Disease. J Alzheimers Dis 42: 1347-1355.

APA - AMERICAN PSYCHIATRIC ASSOCIATION. 2013. Diagnostic and Statistical Manual of Mental Diseases. ( $5^{\text {th }}$ ed.). Arlington, VA: American Psychiatric Publishing.

ARNSTEN AF. 2011. Prefrontal cortical network connections: key site of vulnerability in stress and schizophrenia. Int $\mathrm{J}$ Dev Neurosci 29: 215-223.

BAGDY G AND JUHASZ G. 2013. Biomarkers for personalised treatment in psychiatric diseases. Expert Opin Med Diagn 7: 417-422.

BARCH DM AND SHEFfIELd JM. 2014. Cognitive impairments in psychotic disorders: common mechanisms and measurement. World Psychiatry 13: 224-232.

BARUA A, GHOSH MK, KAR N AND BASILIO MA. 2011. Prevalence of depressive disorders in the elderly. Ann Saudi Med 31: 620-624.

Bauer IE, Pascoe MC, Wollenhaupt-Aguiar B, KAPCZINSKI F AND SOARES JC. 2014. Inflammatory mediators of cognitive impairment in bipolar disorder. $\mathrm{J}$ Psychiatr Res 56: 18-27.

BERRIDGE MJ. 2013. Dysregulation of neural calcium signaling in Alzheimer disease, bipolar disorder and schizophrenia. Prion 7: 2-13. 
BONDI MW, JAK AJ, DELANO-WOOD L, JACOBSON MW, DELIS DC AND SALMON DP. 2008. Neuropsychological contributions to the early identification of Alzheimer's disease. Neuropsychol Rev 18: 73-90.

BRENNER CJ AND SHYN SI. 2014. Diagnosis and Management of Bipolar Disorder in Primary Care: A DSM-5 Update. Med Clin N Am 98: 1025-1048.

BRICKMAN AM, PROVENZANO FA, MURASKIN J, MANLY JJ, BLUM S, APA Z, STERN Y, BROWN TR, LUCHSINGER JA AND MAYEUX R. 2012. Regional white matter hyperintensity volume, not hippocampal atrophy, predicts incident Alzheimer disease in the community. Arch Neurol 69: 1621-1627.

BROMET E ET AL. 2011. Cross-national epidemiology of DSM-IV major depressive episode. BMC Med 9: 90.

Butters MA, Young JB, Lopez O, Aizenstein HJ, Mulsant BH, REYNOLDS CF 3RD, DEKOSKY ST AND BECKER JT. 2008. Pathways linking late-life depression to persistent cognitive impairment and dementia. Dialogues Clin Neurosci 10: 345-357.

Bystad M, Pettersen K And Gronli OK. 2014. [Depression or Alzheimer-type dementia?]. Tidsskr Nor Laegeforen 134: 525-528.

CARTER CJ. 2006. Schizophrenia susceptibility genes converge on interlinked pathways related to glutamatergic transmission and long-term potentiation, oxidative stress and oligodendrocyte viability. Schizophr Res 86: 1-14.

CAsey BJ, Craddock N, Cuthbert BN, Hyman SE, LeE FS AND RESSLER KJ. 2013. DSM-5 and RDoC: progress in psychiatry research? Nat Rev Neurosci 14: 810-814.

CHU LW. 2012. Alzheimer's disease: early diagnosis and treatment. Hong Kong Med J 18: 228-237.

CONTADOR-CASTILlo I, FERNANDEZ-CALVO B, CACHOGUTIERREZ LJ, RAMOS-CAMPOS F AND HERNANDEZMARTIN L. 2009. [Depression in Alzheimer typedementia: is there any effect on memory performance]. Rev Neurol 49: 505-510.

Da Silva J, Goncalves-PEREIRA M, XaVier M AND MuKAETOVA-LADINSKA EB. 2013. Affective disorders and risk of developing dementia: systematic review. Br J Psychiatry 202: 177-186.

DAmadzic R, ShuAngshoti S, Giblen G AND HeRman MM. 2002. Neuritic pathology is lacking in the entorhinal cortex, subiculum and hippocampus in middle-aged adults with schizophrenia, bipolar disorder or unipolar depression. Acta Neuropathol 103: 488-494.

Diniz BS, ButTers MA, ALBERT SM, DEW MA AND REYNOLDS CF 3RD. 2013. Late-life depression and risk of vascular dementia and Alzheimer's disease: systematic review and meta-analysis of community-based cohort studies. Br J Psychiatry 202: 329-335.

Direk N, SCHRIJVERS EM, DE BRUIJN RF, MirZA S, HOFMAN A, IKRAM MA AND TIEMEIER H. 2013. Plasma amyloid beta, depression, and dementia in communitydwelling elderly. J Psychiatr Res 47: 479-485.

DOUAUD G ET AL. 2014. A common brain network links development, aging, and vulnerability to disease. Proc Natl Acad Sci USA 111: 17648-17653.

ETKIN A, GYURAK A AND O'HARA R. 2013. A neurobiological approach to the cognitive deficits of psychiatric disorders. Dialogues Clin Neurosci 15: 419-429.

FERnANDEZ M, GOBARTT AL AND BALANA M. 2010. Behavioural symptoms in patients with Alzheimer's disease and their association with cognitive impairment. BMC Neurol 10: 87.

FRANZ CE, BARKER JC, KIM K, FLORES Y, JENKINS C, KRAVITZ RL AND HINTON L. 2010. When help becomes a hindrance: mental health referral systems as barriers to care for primary care physicians treating patients with Alzheimer's disease. Am J Geriatr Psychiatry 18: 576-585.

FRIEDMAN JI, HARVEY PD, COLEMAN T, MORIARTY PJ, Bowie C, PARRELla M, White L, ADLER D AND DAVIS KL. 2001. Six-year follow-up study of cognitive and functional status across the lifespan in schizophrenia: a comparison with Alzheimer's disease and normal aging. Am J Psychiatry 158: 1441-1448.

GRUNDMAN M ET AL. 2013. Potential impact of amyloid imaging on diagnosis and intended management in patients with progressive cognitive decline. Alzheimer Dis Assoc Disord 27: 4-15.

Haller S, Xekardaki A, Delaloye C, Canuto A, LÖVBlad KO, GOLD G AND GIANNAKOpoulos P. 2011. Combined analysis of grey matter voxel-based morphometry and white matter tract-based spatial statistics in late-life bipolar disorder. J Psychiatry Neurosci 36: 391401.

Harvey PD, White L, Parrella M, Putnam KM, KINCAID MM, POWCHIK P, MOHS RC AND DAVIDSON M. 1995. The longitudinal stability of cognitive impairment in schizophrenia. Mini-mental state scores at one- and twoyear follow-ups in geriatric in-patients. Br J Psychiatry 166: 630-633.

HENEKA MT, KUMMER MP AND LATZ E. 2014. Innate immune activation in neurodegenerative disease. Nat Rev Immunol 14: 463-477.

HERNANDEZ F, LUCAS JJ AND AVILA J. 2013. GSK3 and tau: two convergence points in Alzheimer's disease. J Alzheimers Dis 33(Suppl 1): S141-144.

HOWES OD AND MURRAY RM. 2014. Schizophrenia: an integrated sociodevelopmental-cognitive model. Lancet 383: 1677-1687.

IKEDA Y, YAHATA N, ITO I, NAGANO M, TOYOTA T, YoshikAWA T, OKUBO Y AND SUZUKI H. 2008. Low serum levels of brain-derived neurotrophic factor and epidermal growth factor in patients with chronic schizophrenia. Schizophr Res 101: 58-66. 
JAKOBSSON J, ZETTERBERG H, BLENNOW K, JOHAN EKMAN C, JOHANSSON AG AND LANDEN M. 2013. Altered concentrations of amyloid precursor protein metabolites in the cerebrospinal fluid of patients with bipolar disorder. Neuropsychopharmacology 38: 664-672.

JOYCE EM. 2013. Cognitive function in schizophrenia: insights from intelligence research. Br J Psychiatry 203: 161-162.

KESSING LV AND ANDERSEN PK. 2004. Does the risk of developing dementia increase with the number of episodes in patients with depressive disorder and in patients with bipolar disorder? J Neurol Neurosurg Psychiatry 75: 16621666.

Kessing LV, Olsen EW, MoRTEnsen PB AND ANDERSEN PK. 1999. Dementia in affective disorder: a case-register study. Acta Psychiatr Scand 100: 176-185.

KESSLER RC AND BROMET EJ. 2013. The epidemiology of depression across cultures. Annu Rev Public Health 34: 119-138.

KIM HW, RAPOPORT SI AND RAO JS. 2010. Altered expression of apoptotic factors and synaptic markers in postmortem brain from bipolar disorder patients. Neurobiol Dis 37: 596-603.

KIM HW, RAPOPORT SI AND RAO JS. 2011. Altered arachidonic acid cascade enzymes in postmortem brain from bipolar disorder patients. Mol Psychiatry 16: 419428.

KitA Y, BABA H, MAESHIMA H, NAKANO Y, SUZUKI T AND ARAI H. 2009. Serum amyloid beta protein in young and elderly depression: a pilot study. Psychogeriatrics 9: 180185.

Koenig AM, Bhalla RK And Butters MA. 2014. Cognitive functioning and late-life depression. J Int Neuropsychol Soc 20: 461-467.

KRSTIC D AND KNUESEL I. 2013. Deciphering the mechanism underlying late-onset Alzheimer disease. Nat Rev Neurol 9: 25-34.

KUMAR D, NIZAMIE SH AND JAHAN M. 2008. Activity-based prospective memory in schizophrenia. Clin Neuropsychol 22: 497-506.

LEDO JH, AZEVEDO EP, CLARKE JR, RIBEIRO FC, FIGUEIREDO CP, Foguel D, DE FELICE FG AND FERREIRA ST. 2013. Amyloid-beta oligomers link depressive-like behavior and cognitive deficits in mice. Mol Psychiatry 18: 1053-1054.

LEPAgE M, BOdNAR M AND BOWIE CR. 2014. Neurocognition: clinical and functional outcomes in schizophrenia. Can J Psychiatry 59: 5-12.

LUCHSINGER JA, HoNig LS, TANG MX AND DEVANAND DP. 2008. Depressive symptoms, vascular risk factors, and Alzheimer's disease. Int J Geriatr Psychiatry 23: 922-928.

LYKETSOS CG, CARRILLO MC, RYAN JM, KHACHATURIAN AS, Trzepacz P, AMATNieK J, Cedarbaum J, BRASHEAR R AND MILLER DS. 2011. Neuropsychiatric symptoms in Alzheimer's disease. Alzheimers Dement 7: 532-539.

MONDELLI V ET AL. 2011. Stress and inflammation reduce brain-derived neurotrophic factor expression in firstepisode psychosis: a pathway to smaller hippocampal volume. J Clin Psychiatry 72: 1677-1684.

MURRAY PS, KUMAR S, DEMICHELE-SWEET MAA AND SWEET RA. 2014. Psychosis in Alzheimer's Disease. Biol Psychiat 75: 542-552.

NELSON MD, SAYKIN AJ, FLASHMAN LA AND RIORDAN HJ. 1998. Hippocampal volume reduction in schizophrenia as assessed by magnetic resonance imaging: a meta-analytic study. Arch Gen Psychiatry 55: 433-440.

NiCOLAS G, BEHEREC L, HANNEQUIN D, OPOLCZYNSKI G, Rotharmel M, WALLON D, VERA P, MARTINAUd O, GUILLIN O AND CAMPION D. 2014. Dementia in middleaged patients with schizophrenia. J Alzheimers Dis 39: 809-822.

NIMMRICH V AND EBERT U. 2009. Is Alzheimer's disease a result of presynaptic failure? Synaptic dysfunctions induced by oligomeric beta-amyloid. Rev Neurosci 20: 1-12.

OWNBY RL, CROCCO E, ACEVEDo A, JOHN V AND LOEWENSTEIN D. 2006. Depression and risk for Alzheimer disease: systematic review, meta-analysis, and metaregression analysis. Arch Gen Psychiatry 63: 530-538.

PALANIYAPPAN L, AL-RADAIDEH A, MOUGIN O, GOWLAND P AND LIDDLE PF. 2013. Combined white matter imaging suggests myelination defects in visual processing regions in schizophrenia. Neuropsychopharmacology 38: 1808-1815.

PARADELA EM, LOURENCO RA AND VERAS RP. 2005. [Validation of geriatric depression scale in a general outpatient clinic]. Rev Saude Publica 39: 918-923.

Penzes P, CAHILl ME, JONES KA, VANLEEUWEN JE AND WOOLFREY KM. 2011. Dendritic spine pathology in neuropsychiatric disorders. Nat Neurosci 14: 285-293.

PiCCINNI A, ORIGLia N, VELTRI A, VizzACCARO C, MARAZZITI D, CATENA-DELL'OSSO M, CONVERSANO C, Moroni I, Domenici L AND DELL'OSSO L. 2012. Plasma beta-amyloid peptides levels: a pilot study in bipolar depressed patients. J Affect Disord 138: 160-164.

PotTer GG AND STEFFENS DC. 2007. Contribution of depression to cognitive impairment and dementia in older adults. Neurologist 13: 105-117.

Potvin S, Stip E, SEPEHRY AA, GENDRON A, BAH R AND KOUASSI E. 2008. Inflammatory cytokine alterations in schizophrenia: a systematic quantitative review. Biol Psychiat 63: 801-808.

QUAN M ET AL. 2013. White matter tract abnormalities between rostral middle frontal gyrus, inferior frontal gyrus and striatum in first-episode schizophrenia. Schizophr Res 145: 1-10. 
RAJJI TK, MIRANDA D AND MULSANT BH. 2014. Cognition, function, and disability in patients with schizophrenia: a review of longitudinal studies. Can J Psychiatry 59: 13-17.

RAO JS, KELESHIAN VL, KLEIN S AND RAPOPORT SI. 2012. Epigenetic modifications in frontal cortex from Alzheimer's disease and bipolar disorder patients. Transl Psychiatry 2: e132.

RAO JS, RAPOPORT SI AND KIM HW. 2011. Altered neuroinflammatory, arachidonic acid cascade and synaptic markers in postmortem Alzheimer's disease brain. Transl Psychiatry 1: e31.

RAPP MA, SCHNAIDER-BEERI M, GROSSMAN HT, SANO M, PERL DP, PUROHIT DP, GORMAN JM AND HAROUTUNIAN V. 2006. Increased hippocampal plaques and tangles in patients with Alzheimer disease with a lifetime history of major depression. Arch Gen Psychiatry 63: 161-167.

REITZ C, BRAYNE C AND MAYEUX R. 2011. Epidemiology of Alzheimer disease. Nat Rev Neurol 7: 137-152.

REJ S, ButTers MA, Aizenstein HJ, Begley A, TSAY J, REYNOLDS CF 3RD, MULSANT BH AND GILDENGERS A. 2014. Neuroimaging and neurocognitive abnormalities associated with bipolar disorder in old age. Int $\mathrm{J}$ Geriatr Psychiatry 29: 421-427.

ROBINSON LJ, THOMPSON JM, GALLAGHER P, GOSWAMI U, YOUNG AH, FERRIER IN AND MOORE PB. 2006. A metaanalysis of cognitive deficits in euthymic patients with bipolar disorder. J Affect Disord 93: 105-115.

ROPACKI SA AND JESTE DV. 2005. Epidemiology of and risk factors for psychosis of Alzheimer's disease: a review of 55 studies published from 1990 to 2003 . Am J Psychiatry 162: 2022-2030.

Rosenberg PB, Mielke MM, Appleby B, OH ES, LEOUTSAKOS JM AND Lyketsos CG. 2011. Neuropsychiatric symptoms in MCI subtypes: the importance of executive dysfunction. Int $\mathrm{J}$ Geriatr Psychiatry 26: 364-372.

Rosenberg PB, Mielke MM, APPleby BS, OH ES, GEDA YE AND LYKETSOS CG. 2013. The association of neuropsychiatric symptoms in MCI with incident dementia and Alzheimer disease. Am J Geriatr Psychiatry 21: 685-695.

ROSSLER W, SALIZE HJ, VAN OS J AND RIECHER-ROSSLER A. 2005. Size of burden of schizophrenia and psychotic disorders. Eur Neuropsychopharmacol 15: 399-409.

ROTHENEICHNER P, LANGE S, O'Sullivan A, MARSCHALLINGER J, ZAUNMAIR P, GERETSEGGER C, Aigner L and Couillard-Despres S. 2014. Hippocampal neurogenesis and antidepressive therapy: shocking relations 2014: 723915.

SANSONI J, ANDERSON KH, VARONA LM AND VARELA G. 2013. Caregivers of Alzheimer's patients and factors influencing institutionalization of loved ones: some considerations on existing literature. Ann Ig 25: 235-246.
SCHAEFER J, GIANGRANDE E, WEINBERGER DR AND DICKINSON D. 2013. The global cognitive impairment in schizophrenia: consistent over decades and around the world. Schizophr Res 150: 42-50.

SCHALLER S, MAUSKOPF J, KRIZA C, WAHLSTER P AND KOLOMINSKY-RABAS PL. 2014. The main cost drivers in dementia: a systematic review. Int J Geriatr Psychiatry 30: 111-129.

SCHIFFCZYK C, ROMERO B, JONAS C, LAHMEYER C, MULLER F AND RIEPE MW. 2013. Appraising the need for care in Alzheimer's disease. BMC Psychiatry 13: 73.

SCHIPPER HM. 2011. Apolipoprotein E: implications for AD neurobiology, epidemiology and risk assessment. Neurobiol Aging 32: 778-790.

SCHIZOPHRENIA WORKING GROUP OF THE PSYCHIATRIC GENOMICS CONSORTIUM. 2014. Biological insights from 108 schizophrenia-associated genetic loci. Nature 511: 421427.

SERINO S, CIPRESSO P, MORGANTI F AND RIVA G. 2014. The role of egocentric and allocentric abilities in Alzheimer's disease: a systematic review. Ageing Res Rev 16: 32-44.

SERRANO-POZO A, Frosch MP, MASLIAH E AND HYMAN BT. 2011. Neuropathological alterations in Alzheimer disease. Cold Spring Harb Perspect Med 1: a006189.

SHANKAR GM AND WALSH DM. 2009. Alzheimer's disease: synaptic dysfunction and Abeta. Mol Neurodegener 4: 48.

SODHI SK, LiNder J, CHENARd CA, Miller DEL D, HAYNES WG AND FIEDOROWICZ JG. 2012. Evidence for accelerated vascular aging in bipolar disorder. J Psychosom Res 73: 175-179.

STEFFENS DC, FISHER GG, LANGA KM, POTTER GG AND PLASSMAN BL. 2009. Prevalence of depression among older Americans: the Aging, Demographics and Memory Study. Int Psychogeriatr 21: 879-888.

STICH O, ANDRES TA, GROSS CM, GERBER SI, RAUER S AND LANGOSCH JM. 2014. An observational study of inflammation in the central nervous system in patients with bipolar disorder. Bipolar Disord 17: 291-302.

STUTZMANN GE, SMITH I, CACCAMO A, ODDO S, LAFERLA FM AND PARKER I. 2006. Enhanced ryanodine receptor recruitment contributes to $\mathrm{Ca} 2+$ disruptions in young, adult, and aged Alzheimer's disease mice. J Neurosci 26: 5180-5189.

THIELsCHER C, THIElscher S AND KOSTEV K. 2013. The risk of developing depression when suffering from neurological diseases. Ger Med Sci 11: Doc02.

TING KK, BREW BJ AND Guillemin GJ. 2009. Effect of quinolinic acid on human astrocytes morphology and functions: implications in Alzheimer's disease. J Neuroinflammation 6: 36.

TSOPElas C, STEWART R, SAVVA GM, BRAYNE C, INCE P, THOMAS A AND MATTHEWS FE. 2011. Neuropathological 
correlates of late-life depression in older people. Br J Psychiatry 198: 109-114.

VAHIA VN. 2013. Diagnostic and statistical manual of mental disorders 5: A quick glance. Indian J Psychiatry 55: 220223.

VOEVOdSKAYA O, SIMMONS A, NORDENSKJOLD R, Kullberg J, AHLSTROM H, Lind L, WAHLUND LO, LARSSON EM AND WESTMAN E. 2014. The effects of intracranial volume adjustment approaches on multiple regional MRI volumes in healthy aging and Alzheimer's disease. Front Aging Neurosci 6: 264.

WHO - World Health ORganization. 2012. Dementia cases set to triple by 2050 but still largely ignore. Geneva: World Health Organization.

WILSON RS, SCHNEIDER JA, BIENIAS JL, ARNOLD SE, EVAns DA AND BennetT DA. 2003. Depressive symptoms, clinical AD, and cortical plaques and tangles in older persons. Neurology 61: 1102-1107.

Wood SJ, Pantelis C, ProfFitT T, Phillips LJ, StUart GW, BUCHANAN JA, MAHONY K, BREWER W, SMITH DJ AND MCGORRY PD. 2003. Spatial working memory ability is a marker of risk-for-psychosis. Psychol Med 33: 1239-1247.
WOODWARD ND, DUFFY B AND KARBASFOROUSHAN H. 2013. Prefrontal cortex activity during response selection predicts processing speed impairment in schizophrenia. J Int Neuropsychol Soc 19: 782-791.

Wright IC, RABE-HeSketh S, WoOdRufF PW, DAVID AS, Murray RM AND Bullmore ET. 2000. Metaanalysis of regional brain volumes in schizophrenia. Am J Psychiatry 157: 16-25.

YAFFE K, BLACKWELL T, GORE R, SANDS L, REUS V AND BROWNER WS. 1999. Depressive symptoms and cognitive decline in nondemented elderly women: a prospective study. Arch Gen Psychiatry 56: 425-430.

YAFFE K, MidDleton LE, Lui LY, SPIRA AP, STONE K, RACINE C, ENSRUd KE AND KRAMER JH. 2011. Mild cognitive impairment, dementia, and their subtypes in oldest old women. Arch Neurol 68: 631-636.

ZILKENS RR, BRUCE DG, DUKE J, SPILSBURY K AND SEMMENS JB. 2014. Severe psychiatric disorders in midlife and risk of dementia in late- life (age 65-84 years): a population based case-control study. Curr Alzheimer Res 11: 681-693. 